\title{
Exploring hydraulic redistribution for water management in gardens
}

\author{
S.V. Lourenço ${ }^{1}$, M.I. Ferreira ${ }^{1}{ }^{2}$ \\ ${ }^{1}$ Departamento de Ciências e Engenharia de Biossistemas, DCEB; Instituto Superior de \\ Agronomia (ISA), Universidade de Lisboa, \\ ${ }^{2}$ Linking Landscape, Environment, Agriculture and Food (LEAF), Instituto Superior de \\ Agronomia, Universidade de Lisboa, Tapada da Ajuda, 1349-017 Lisboa, Portugal, \\ isabelferreira@isa.ulisboa.pt
}

\begin{abstract}
The understanding of water use by mixed stands, where trees and herbaceous share the same area, as in landscaping, requires at least the combined consideration of the role of water and radiation, as limiting factors for plant development and survival. Hydraulic redistribution (HR), a mechanism of transport of water between different root zones via roots, is of high interest in this context. Several studies in last decades, using bidirectional sap flow sensors in roots, and other tools, unlighted the role of this survival mechanism in potentially critical hydro-climatic conditions, i.e., when plants are subjected to severe water stress. Woody plants can act as water transporters from underground deep layers to shallow soil layers, via their deep roots, as a result of water potential gradients. Results from literature suggest that in doing so (HR) deep rooted plants not only ensure conditions for their own survival but also that, at certain stages, they increase the survival chances for other plants installed in nearby shallow layers. Our hypothesis is that synergies between species exploring water from different soil layers can be identified in a simple experiment, the results being of potential interest for garden planning. We show preliminary results obtained with olive trees in Mediterranean climatic conditions, and associated herbaceous plants, in a kind of splitroot experiment. Water status of herbaceous plants in three different conditions was evaluated from leaf water potential and stomatal conductance. The results confirm our hypothesis in that herbaceous plants were significantly affected by water applied to part of the root system, even if not receiving irrigation directly. This mechanism should be taken into account when creating sustainable urban gardens, in respect to water management.
\end{abstract}

Keywords: water stress, irrigation, mixed stands, Mediterranean, landscaping.

\section{INTRODUCTION}

In mixed stands, trees and herbaceous share the same area, and its interaction requires considering the role of water and radiation, as limiting factors for plant development and survival. Concerning water use, hydraulic redistribution (HR) is of high interest for the herbaceous, as a mechanism of transport of water between different root zones via roots. Woody plants can act as water transporters from underground deep layers to shallow roots, as a result of water potential gradients (Nadezhdina et al., 2010). Several studies in last decades, used bidirectional sap flow sensors in roots and chemical markers, to analyse the role of this survival mechanism in potentially critical hydro-climatic conditions, namely under high atmospheric driving forces and severe edaphic water stress. Using HR, deep rooted plants, such as olive trees (Nadezhdina et al., 2011, 2014; Ferreira et al., 2012b, 2013, 2018) ensure conditions for the survival of their shallow roots in summer and consequently to their own survival in rainy seasons, when shallow roots have a key role. 
Our hypothesis is that, at certain stages, the old olive trees used in this experiment increase the survival chances of other plants installed in nearby shallow layers, the results being of potential interest for garden planning. We tested if synergies between species exploring different soil layers could be preliminary identified in a simple experiment in natural conditions, by quantifying the water status of herbaceous plants.

\section{MATERIALS AND METHODS}

The experiment took place in central Portugal, under Mediterranean climatic conditions (transition between Csa and Csb, www.ipma.pt, Figure 1a), in late September of the very dry hydrological year of 2016-2017, as described below. Rainfed olive trees (aged between 70 and 100 years) and spontaneous herbaceous plants sharing the ground were used, in a kind of split-root experiment. The soil was a loamy sand with a depth (above schist or granite derived coarse materials quite variable $(40 \mathrm{~cm}$ to $1 \mathrm{~m})$.

This hydrological year (1 October 2016 to 30 September 2017) combined the driest and warmest situation recorded in Portugal since 1931, for the period April- September, the temperature being the highest and the precipitation the second lowest (Figure 1b).

Consequently, the estimated total available water for the region, till $1 \mathrm{~m}$ depth, was below 20\% (IPMA, 2017) and the upper soil (at least $40 \mathrm{~cm}$ ) was for several months at permanent wilting point, as it comes from our estimates of its water balance.

A circle of about $2 \mathrm{~m}$ around rainfed olive trees was divided in two half circles, by 30 $\mathrm{cm}$ deep and large trenches, to ensure that roots from herbaceous plants were not crossing borders between the two sub-areas. One of the half circles (I, which stands for irrigated) was irrigated with low flow to prevent runoff, while the other was kept in dry soil as before (S_IO, stress plants around irrigated olive tree).

The herbaceous plants that occurred naturally around olive trees, during late summer, in this rained orchard belong to the species Pteridium aquilinum ssp. Latiusculum (an invasive species, at this stage 15 to $40 \mathrm{~cm}$ high) and Vinca minor (5 to $15 \mathrm{~cm}$ high). Furthermore, due to some Prunus spinose trees at one edge of the plot, correspondent young plants $(20$ to $60 \mathrm{~cm}$ high) were growing spontaneously around some nearby olive trees and were also used.

During this short experiment (day of the year 266 and 267, i.e., the $23^{\text {rd }}$ and $24^{\text {th }}$ of September), water status of herbaceous plants was evaluated by predawn (PLWP) and noon leaf water potential (NLWP) measured with a Scholander pressure chamber ( $\mathrm{n}=4$ to 8 , depending on scattering observed). Some complementary data were obtained on stomatal conductance $\left(\mathrm{g}_{\mathrm{s}}\right)$ measured with a LICOR 1600 steady-state porometer $(\mathrm{n}=2$ to 6$)$. These measurements were taken in the olive trees and herbaceous plants around (I, S_IO), as well as in distant herbaceous plants not influenced by the irrigation of the olive trees (S_SO, stressed plants around stress olive tree).

\section{RESULTS}

Concerning the specimens of Pteridium aquilinum, the average (2 days) PLWP observed in irrigated plants (I) was quite high $(-0.06 \pm 0.08 \mathrm{MPa})$ and significantly different from the lower water potential of stressed plants near stressed olive trees (S_SO, with $-0.35 \pm 0.04$ $\mathrm{MPa}$ ), as expected (Figure 2). The plants installed in dry soil near the irrigated olive tree (S_IO) showed values on average $(-0.12 \pm 0.08 \mathrm{MPa})$ closer to those under treatment $\mathrm{I}$, as we considered it could happen, and far from the S_SO plants, in spite of no irrigation. This is the answer we are interested in analyzing.

The NLWP values for Pteridium aquilinum plants show a less clear answer, with S_IO plants displaying intermediate values (Figure 2) but closer to S_SO plants. Due to the shape of Pteridium aquilinum leaves, $\mathrm{g}_{\mathrm{s}}$ could not be measured with our available tools for the porometer.

For Vinca minor plants, the same measured above (in Pteridium aquilinum) applies to PLWP $(0.00 \pm 0.00,-0.24 \pm 0.03$ and $-0.79 \pm 0.50 \mathrm{MPa}$, for I, S_IO and S_SO, respectively). Therefore, the water status of stressed plants near the irrigated tree was clearly influenced 
by the tree, being the plants under rainfed conditions the ones with lower values of PLWP in relation to the other species observed, thought with high scattering in these stressed plants (far from the irrigated tree, S_SO plants) which is likely explained by the spatial heterogeneity in conditions of access of nearby olive trees to deep water, independently of irrigation and also to the shallow roots of these small plants.

The observed noon average $g_{s}$ for Vinca minor plants was $141.0 \pm 14.4,34.5 \pm 21.2$ and $22.3 \pm 8.6 \mathrm{mmol} \mathrm{m}^{-2} \mathrm{~s}^{-1}$, respectively for I, S_IO and S_SO) which suggests that at noon the S_IO and S_SO had similar behavior (in relation to I plants with much higher conductance), but still with a slight difference between those influenced by the irrigated tree and those closer to rainfed trees.

Concerning Prunus spinosa plants, only NLWP could be observed. The results $0.98 \pm$ $0.10,0.88 \pm 0.06$ and $0.93 \pm 0.06 \mathrm{MPa}$ for I, S_IO and S_SO, respectively) suggest absolutely no visible effect of irrigation on young plants, at noon. This was confirmed by $\mathrm{g}_{\mathrm{s}}$ observations also at noon, where the lack of significant differences between the three different conditions was observed $\left(126.5 \pm 18.5,106.3 \pm 24.4\right.$ and $111.6 \pm 24.7 \mathrm{mmol} \mathrm{m}^{-2} \mathrm{~s}^{-1}$, for I, S_IO, and S_SO plants, respectively).

As for the olive trees observed, PLWP was slightly below the values observed for the low plants, while NLWP (at noon) was not significantly different between both situations, being on average $2.53 \mathrm{MPa}$, suggesting an isohydric behaviour (Ferreira et al., 2012b; Ferreira 2017; 2017, Blanco-Cippolone et al., 2017). Consistently, at noon, $\mathrm{g}_{\mathrm{s}}$ of irrigated trees was $132.2 \pm 18.5 \mathrm{mmol} \mathrm{m}^{-2} \mathrm{~s}^{-1}$ and for rainfed trees it was $93.3 \pm 28.5 \mathrm{mmol} \mathrm{m}^{-2} \mathrm{~s}^{-1}$ (approximately 3.28 and $2.32 \mathrm{~m} / \mathrm{s}$ ).

\section{DISCUSSION}

The fact that we used olive trees for this experiment comes from the experience gathered during a 3 years experiment with rained and irrigated olive orchards, dedicated to analyse water use (Conceição et al., 2017, 2018) and the role of HR (Nadezhdina et al., 2014; Ferreira et al., 2012b, 2013, 2018). Those experiments considered in an integrated analysis show that the olive trees capacity of surviving under atmospheric and edaphic stress is highly explained by the ability to uptake water from much larger soil volumes than those usually considered. Consequently, these trees when well established have developed the ability to explore deep soil, bringing it to the upper roots. The sap flow sensors installed in roots cannot demonstrate the possibility that the water brought to upper roots is transferred to the soil to the possible benefit of herbaceous plants. This possibility was here analysed and preliminary confirmed by the changes in water status of herbaceous plants that were installed in soil at the permanent wilting point, when nearby trees receive water in the other half of the shallow part of their root system.

The variable PLWP was responsive in this respect, while NLWP or $g_{s}$ were not, which makes sense for plants that have an isohydric behaviour, but also possibly because at noon the part of the soil-plant-atmosphere continuum that has lower total water potential is the atmosphere. This suggests that, at this time of the day, not only shallow olive trees are extracting small amounts of water from the shallow soil (Nadezhdina et al., 2014; Ferreira et al., 2013, 2018) but also herbaceous plants do so. Therefore, at noon the water status of S_IO plants is almost as critical as the rainfed plants far from the rainfed olive trees (S_SO).

Further and more complete experiments are required to confirm that our hypothesis of synergy between vegetation layers is valid and that PLWP is appropriate to verify its validity.

\section{CONCLUSIONS}

These preliminary results seem to confirm our hypothesis in that these herbaceous plants were significantly affected by water applied to part of the root system of a neighbouring tree, even if not receiving irrigation directly. Therefore, hydraulic redistribution to the upper soil layers affects herbaceous plants with no access to deep water, via the roots of olive trees. This mechanism that works to the profit of the herbaceous should be taken into account when creating sustainable urban gardens, in respect to water management. 


\section{ACKNOWLEDGEMENTS}

Project WAter Saving in Agriculture (WASA): Technological developments for the sustainable management of limited water resources in the Mediterranean area (ERANETMED/FCT).

\section{Literature cited}

Blanco-Cipollone, F., Lourenço, S., Silvestre, J., Conceição, N., Moñino, M., Vivas, A., and Ferreira, M.I. (2017). Plant Water Status Indicators for Irrigation Scheduling Associated with Iso- and Anisohydric Behavior: Vine and Plum Trees. Horticulturae 3 (3), 4764 https://doi.org/10.3390\%2Fhorticulturae3030047

Conceição, N., Tezza. L., Lourenço, S., Häusler, M., Boteta, L., Pacheco, C.A., and Ferreira M.I. (2018). Importance of very fine roots in deep soil layers for the survival of rainfed olive trees. Acta Hortic. 1199, 57-62 https://doi.org/10.17660/ActaHortic.2018.1199.9

Conceicão, N., Tezza, L., Häusler, M., Lourenco, S., Pacheco, C.A., and Ferreira, M.I. (2017). Three years of monitoring evapotranspiration components and crop and stress coefficients in a deficit-irrigated intensive olive orchard. Agric. Water Manag. 191, 138-152 http://dx.doi.org/10.1016/i.agwat.2017.05.011

IPMA 2017. Instituto Português do Mar e da Atmosfera, I.P. Divisão de Clima e Alterações Climáticas. Boletim Climatológico Set. 2017 Mensal e Ano Hidrológico

http://www.ipma.pt/resources.www/docs/im.publicacoes/edicoes.online/20171013/kOqtdIUPrEKkqtxFnawS Lcli 2017090120170930 pcl mm co pt.pdf

Ferreira, M.I. (2017). Stress coefficients for soil water balance combined with water stress indicators for irrigation scheduling of woody crops. Horticulturae 3 (2), 38 https://doi.org/10.3390/horticulturae3020038

Ferreira, M.I., Conceição, N., Pacheco, C.A., and Green, S. (2012a). 0 que fazem as oliveiras de noite ou redistribuição hidráulica num olival de sequeiro no Alentejo. Proceedings VI Simpósio Nacional de Olivicultura (Mirandela, 15-17 Novembro 2012), 67-76 http://aphorticultura.pt/pdf/Indice_Atas_Portuguesas_de_Horticultura-14.pdf

Ferreira, M.I., Conceição, N., Pacheco, C.A., and Häusler, M. (2012b). Análise de indicadores de desconforto hídrico durante ciclos de stress num olival intensivo no Alentejo. Proceedings VI Simpósio Nacional de Olivicultura (Mirandela, Nov 2012), 207-216 http://aphorticultura.pt/pdf/Indice_Atas_Portuguesas_de_Horticultura-21.pdf

Ferreira, M.I., Conceição, N., David, T.S., and Nadezhdina, N. (2013). Role of lignotuber versus roots in the water supply of rainfed olives. Acta Hortic. 991,181-188 http://www.actahort.org/books/991/991_22.htm.

Ferreira, M.I., Green, S., Conceição, N., and Férnandez, J.E. (2018). Assessing hydraulic redistribution with the compensated average gradient heat-pulse method on rain-fed olive trees. Plant and Soil 425: 21-41. https://doi.org/10.1007/s11104-018-3585-x

Nadezhdina, N., David, T.S., David, J.S., Ferreira, M.I., Dohnal, M., Tesar, M., Gartner, K., Leitgeb, E., Nadezhdin, V., Cermak, J., Jimenez, M.S., and Morales, D. (2010). Trees never rest: the multiple facets of hydraulic redistribution. Ecohydrol. SI 3 (4), 431-444. Wiley Inter Science (www.interscience.wiley.com) https://doi.org/10.1002/eco.148

Nadezhdina, N., David, T.S., David, J.S., Nadezhdina, V., Ferreira, M.I., Conceição, N., Dohnal, M., Tesar, M., Gartner, K., Ceulemans, R. (2011). Root Function: In Situ Studies through Sap Flow Research. In: S Mancuso (Ed.). Measuring Roots. An updated approach. Springer. Cap 14, 267-290 http://link.springer.com/chapter/10.1007/978-3-64222067-8 14\#

Nadezhdina, N., Ferreira, M., Conceição, N., Pacheco, C., Häusler, M., and David, T. (2014). Water uptake and hydraulic redistribution under a seasonal climate: long-term study in a rainfed olive orchard. Ecohydrology. http://dx.doi.org/10.1002/eco.1545 


\section{Figures}
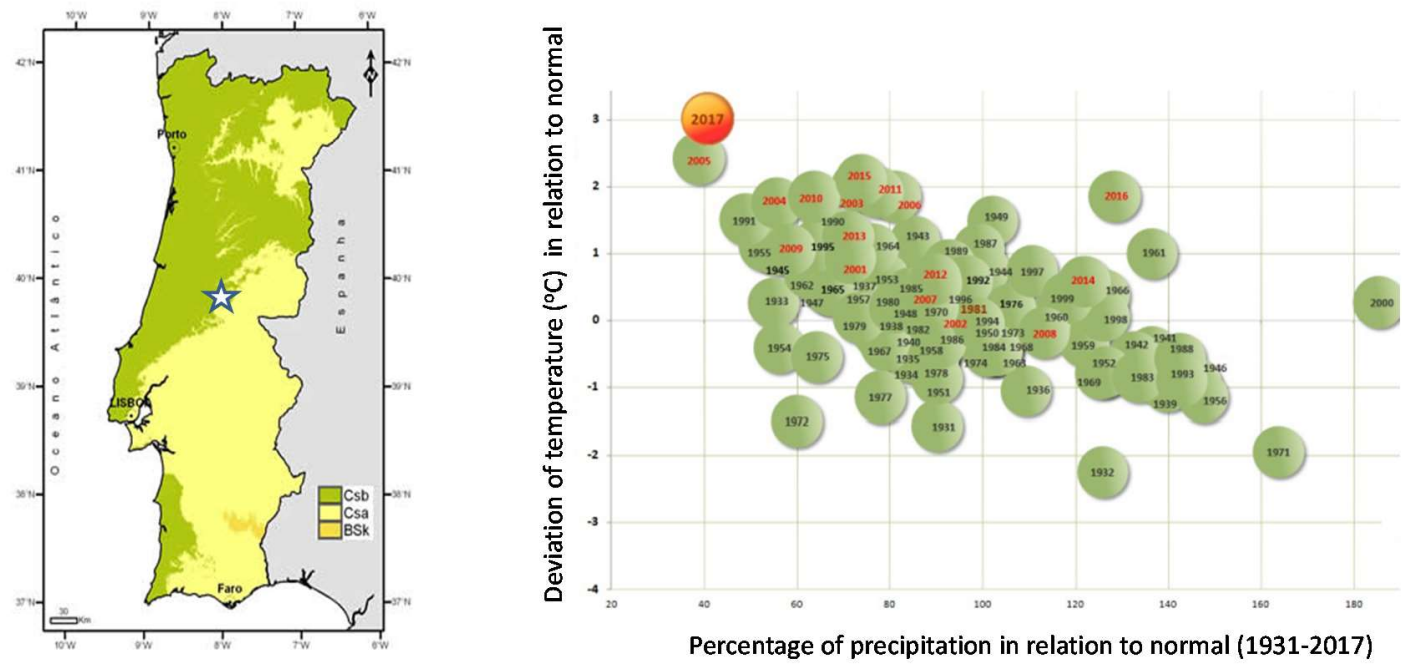

Figure 1. Location of the experiment in Portugal (a), at the edge between Csb and Csa climate (Köppen classification, IPMA, 2017) and (b) position of the hydrological year of the experiment (2017) in relation to average temperature and precipitation; 2017 being the driest and warmest since 1931 (adapted from IPMA, 2017).

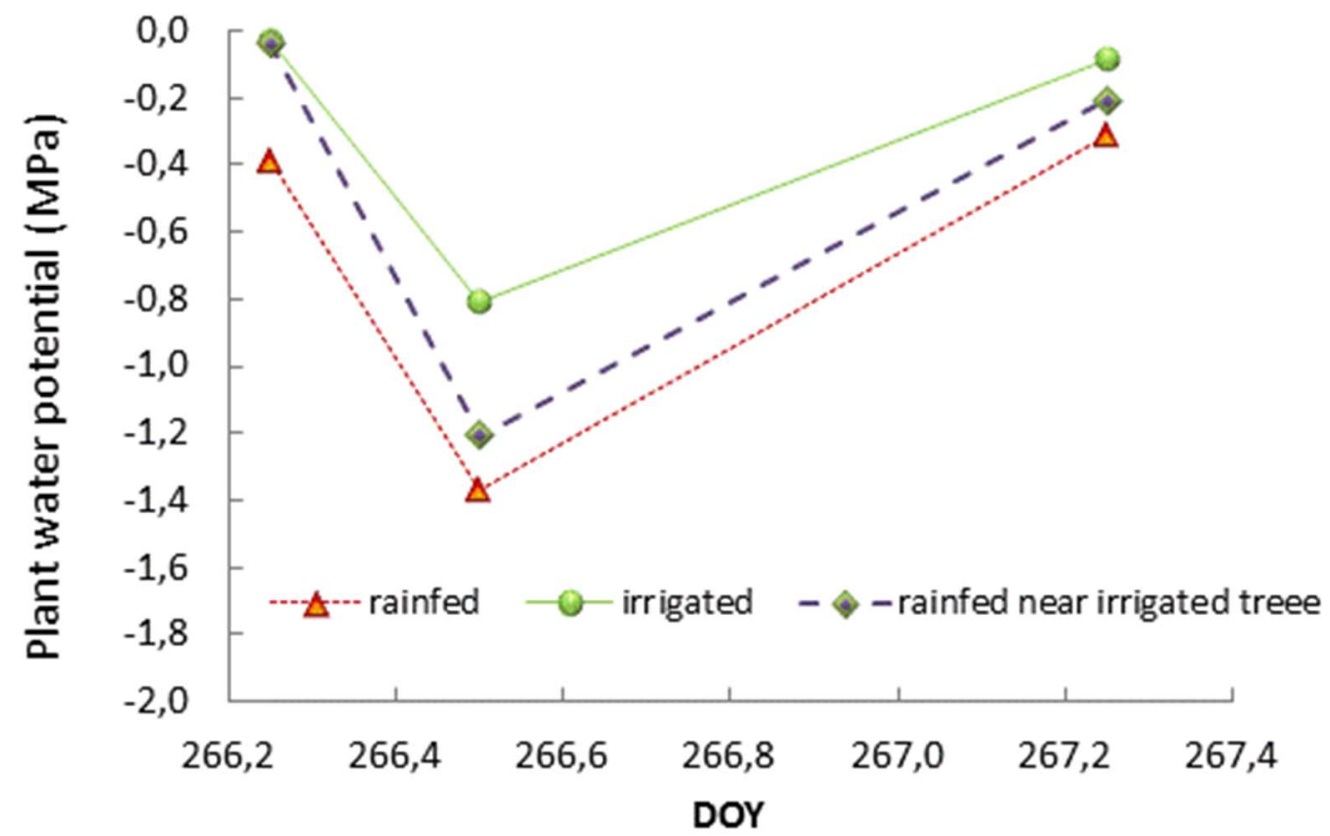

Figure 2. Water status of herbaceous species (Pteridium aquilinum) linked to neighboring olive tree with split roots (S_IO, see text) compared to irrigated (I) and stressed herbaceous near rainfed olive tree (S_SO), evaluated by PLWP (Day Of the Year: 266.3 and 267.3) and SLWP (DOY 266, 24th September 2017, DOY 267.5) in 6 to 9 leaves. 